\title{
TATTARIN KEMIALLINEN KOOSTUMUS JA TATTARISSA ESIINTYVÄT POTENTIAALISESTI TERVEYSVAIKUTTEISET YHDISTEET
}

\author{
Juha-Matti Pihlava ${ }^{1)}$ ja Marjo Keskitalo ${ }^{2)}$ \\ ${ }^{1)}$ MTT laboratoriot, 31600 Jokioinen, juha-matti.pihlava@mtt.fi \\ ${ }^{2)}$ MTT Kasvintuotannon tutkimus, 31600 Jokioinen, marjo.keskitalo@mtt.fi
}

\section{Tiivistelmä}

Tattarin pääkomponentti on tärkkelys, jonka pitoisuus vaihtelee 55-75 \% välillä. Tärkkelyksestä 4-7 \% on ns. resistentissä eli ei-imeytyvässä muodossa. Tattarin kokonaiskuitupitoisuus vaihtelee $5-11 \%$ välillä. Kokonaisessa kuoritussa pähkylässä liukenemattoman kuidun osuus on suhteellisen alhainen (n. 2 \%) ja liukoisen kuidun osuus kaksin-kolminkertainen liukenemattomaan verrattuna. Liukoisen kuidun koostumusta ei ole tarkkaan tutkittu.

Tattarin proteiinipitoisuus on 13-17 \%. Proteiinin aminohappokoostumus on ravitsemuksellisesti hyvälaatuista. Proteiinin sulautuvuus on sitä vastoin huono, johtuen tattarissa olevista lämpökäsittelyä sietävistä proteaasi-inhibiittoreista. Toisaalta juuri tämän ominaisuuden takia huonosti sulavaan proteiiniin on myös liitetty terveysvaikutuksia kuten veren kolesterolipitoisuuden aleneminen ja alentunut riski sairastua paksusuolen syöpään.

Tattarin tärkeimpänä antioksidatiivisena yhdisteenä on perinteisesti pidetty rutiini nimistä flavonoidiglykosidia. Tosiasiassa rutiini ja muut flavonoidit sijaitsevat suuremmissa pitoisuuksissa pähkylän kuoressa eikä niinkään elintarvikkeena käytettävässä kuoritussa pähkylässä. Kuorittu pähkylä sisältää sitä vastoin erittäin antioksidatiivisia proantosyanidiineja eli ns. kondensoituneita tanniineja. Nämä yhdisteet vaikuttavat myös osaltaan tattarin proteiinin huonoon sulavuuteen.

Tattariin liittyvistä terveysvaikutteisista yhdisteistä viime aikoina tutkituimpia ovat olleet D-kiro-inositolia sisältävät mono,- di- ja trigalaktosidit eli fagopyritolit. Rotilla tehdyissä in vivo -kokeissa fagopyritolien on todettu alentavan seerumin glukoositasoa ja tätä kautta mahdollisesti auttavan 2 tyypin diabeteksen kontrollointia.

Viimeaikaisten tutkimustulosten mukaan tattarista löytyy yhdisteitä, jotka inhiboivat elimistön verenpainetta kohottavaa entsyymiä (ACE). Toistaiseksi tutkimukset perustuvat in-vitro kokeisiin ja kliiniset näytöt puuttuvat, mutta tulokset antavat silti uutta potkua tattarin tutkimukseen.

\section{Asiasanat}

Tattari, kemiallinen koostumus, fagopyritolit, flavonoidit, pienkomponentit 
Tattarin pääkomponentti on tärkkelys, jonka pitoisuus vaihtelee 55-75 \% välillä. Tärkkelyksestä 4-7 \% on ns. resistentissä eli ei-imeytyvässä muodossa. Resistentin tärkkelyksen määrää voidaan vielä lisätä prosessoitaessa tattaria elintarvikkeiksi. Ravinnon resistentti tärkkelys tasaa veren sokeripitoisuutta. Lisäksi ruoansulatusjärjestelmän läpi matkaava resistentti tärkkelys pienentää välillisesti myös riskiä sairastua paksusuolen syöpään. Fermentoidessaan resistenttiä tärkkelystä paksusuolessa mikrobit tuottavat lyhytketjuisia rasvahappoja, jotka kiihdyttävät suolen seinämän solujen uusiutumista.

Tattarin kokonaiskuitupitoisuus vaihtelee 5-11 \% välillä. Kokonaisessa kuoritussa pähkylässä liukenemattoman kuidun osuus on suhteellisen alhainen (n. 2 \%) ja liukoisen kuidun osuus kaksinkolminkertainen liukenemattomaan verrattuna. Liukoisen kuidun koostumusta ei ole tarkkaan tutkittu.

Tattarin proteiinipitoisuus on 13-17 \%. Proteiinin aminohappokoostumus on ravitsemuksellisesti hyvälaatuista. Proteiinin sulautuvuus on sitä vastoin huono, johtuen tattarissa olevista lämpökäsittelyä sietävistä proteaasi-inhibiittoreista. Toisaalta juuri tämän ominaisuuden takia huonosti sulavaan proteiiniin on myös liitetty terveysvaikutuksia kuten veren kolesterolipitoisuuden aleneminen ja alentunut riski sairastua paksusuolen syöpään.

Tattarin tärkeimpänä antioksidatiivisena yhdisteenä on perinteisesti pidetty rutiini nimistä flavonoidiglykosidia, jota on kuoritussa pähkylässä $5,7 \pm 0,8 \mathrm{mg} / 100 \mathrm{~g}$ tp $(\mathrm{n}=21)$. Tosiasiassa rutiini ja muut flavonoidit, kuten C-glykosidiset viteksiini, isoviteksiini ja hyperiini, sijaitsevat suuremmissa pitoisuuksissa pähkylän kuoressa eikä niinkään elintarvikkeena käytettävässä kuoritussa pähkylässä. Tattarin kuoressa flavonoidien pitoisuudet ovat: rutiini $17,1 \pm 2,9 \mathrm{mg} / 100 \mathrm{~g}$ tp, viteksiini $22,8 \pm 3,5 \mathrm{mg} / 100 \mathrm{~g}$ tp, isoviteksiini $24,8 \pm 4,9 \mathrm{mg} / 100 \mathrm{~g}$ tp ja hyperiini $6,1 \pm 2,1 \mathrm{mg} / 100 \mathrm{~g}$ tp ( $\mathrm{n}=10)$. Kuorittu pähkylä sisältää kohtalaisia määriä (210 $\pm 39 \mathrm{mg} / 100 \mathrm{~g}$ tp, $\mathrm{n}=21)$ antioksidatiivisia proantosyanidiineja eli ns. kondensoituneita tanniineja. Nämä yhdisteet vaikuttavat myös osaltaan tattarin proteiinin huonoon sulavuuteen.

Tattariin liittyvistä terveysvaikutteisista yhdisteistä viime aikoina tutkituimpia ovat olleet D-chiro-inositolia sisältävät mono,- di- ja trigalaktosidit eli fagopyritolit. Rotilla tehdyissä in vivo -kokeissa fagopyritolien on todettu alentavan seerumin glukoositasoa ja tätä kautta mahdollisesti auttavan 2 tyypin diabeteksen kontrollointia.

Viimeaikaisten tutkimustulosten mukaan tattarista löytyy yhdisteitä, jotka inhiboivat elimistön verenpainetta kohottavaa entsyymiä (ACE). Toistaiseksi tutkimukset perustuvat in-vitro kokeisiin ja kliiniset näytöt puuttuvat, mutta tulokset antavat silti uutta potkua tattarin tutkimukseen. MTT:n ja BioTRIM erotusteknologiakeskuksen valmistamassa tattarikuoren kuiva-uutteessa on myös havaittu ACEinhibitioaktiivisuutta. ACE-aktiivisuuden inhibitiota aiheuttaviksi yhdisteiksi on kirjallisuudessa esitetty 2hydroksinikotianamiinia ja tripeptidi Gly-Pro-Pro:a.

Tattarin mahdollisesti terveysvaikutteisista yhdisteistä toistaiseksi vähälle huomiolle on jäänyt iminosokeri l. typpeä sisältävä sokeri fagomiini. Alustavien tutkimusten mukaan tämä yhdiste alentaa veren sokeripitoisuutta vahvistamalla insuliinin eritystä.

Tattarin yhtenä haitallisimmista yhdisteistä voidaan pitää fagopyriiniä. Tätä yhdistettä esiintyy esim. tattarin vihreissä versoissa, joiden käyttöä elintarvikkeena onkin syytä välttää. Yhdiste aiheuttaa herkistymistä auringon valolle. Oireina on ihon kutinaa ja pahimmassa tapauksessa ihon "palaminen" rakkuloille. Tattarin iduista tekemässämme uutteessa havaittiin LC-PDA-ESI-MS -määrityksessä ainakin 8 erilaisia fagopyriinin muotoa. Yhdisteiden rakenteiden selvittämistä jatketaan. 